\title{
OPTIMALISASI PENDAYAGUNAAN DANA INFAQ- SEDEKAH DALAM MENINGKATKAN PENDAPATAN PETANI DENGAN PROGRAM ALSINTAN (STUDI KASUS PADA DESA SALEH JAYA BANYUASIN SUMATERA SELATAN)
}

\author{
Citra Lestari \\ Universitas Islam Negeri Raden Fatah, Palembang, Indonesia \\ citralestarime@gmail.com
}

\begin{abstract}
Infaq is a asset that is issued by a person or business outside of zakat for general care. Therefore, the substance of the matter is more than the substance of zakat. As for the words of Allah SWT. Even though it is true that there has been a provision of everything to someone else who wants to get the price from God. The study investigated the Optimization of Benefits and Alms in increasing farm income with the Alsintan program in the village of Saleh Jaya, Banyuasin, South Sumatra. Then the methodology used in this research is mixed methods research, where this research can be interpreted as a research method that combines two research methods at once, namely qualitative and quantitative in a research activity which will later obtain more comprehensive, valid, reliable, and objective data. Conclusions in this research are the first Gathering and Funding Development Funding is collected by the community of the Board of Management of the Mosque (BKM), Amil Zakat Institution (LAZ), Amil Zakat Agency (BAZ), Baitul Mal wa Tamwil (BMT), or other institutions. The funds are collected and will be managed properly by the institutions concerned. The second management of the Alms-Infaq Fund is every month that the farmers who are in this wealthy farmer who have the means to have a superior in their agricultural activities are always doing it and are rewarded. The third use of the Alsintan Program in Ummah Welfare is by increasing efficiency, productivity, and cover agricultural products. Increased efficiency, productivity and closure of agricultural products require the handling of agricultural mechanization, beside very determined by capital and human resources quality.
\end{abstract}

Key words: Infaq, Alms, Alsintan

\section{PENDAHULUAN}

Meningkatnya kesadaran tiap manusia sebagai mahluk yang beragama sekarang ini dalam mensyiarkan agama dan mempraktekan perintah-perintah agama sudah sangat terasa bukan saja menyentuh masyarakat di perkotaan namun sudah pula sampai ke daerah pedesaan. Ketersentuhan tersebut tergambar bukan saja dalam praktek ibadah wajib keseharian, namun juga ibadah sunnah. Perintah dan larangan agama sudah menjadi ibadah kebiasaan yang mulai terasa gaungnya pada semangat bermuamalah kepada lingkungan sekitar. Seperti praktek penggalangan dana zakat, wakaf, sedekah dan infaq.

Sebagaimana sedekah, pemanfaatan dana infaq sudah mulai dipikirkan orang dalam mensiarkan agama dan mendayagunakannya demi kesejahteraan ummat seluruhnya. Sedekah dan infaq yang dulu masih dianggap sebagai perintah yang sunnah dan tidak wajib atau dalam artian dilakukan kapan saja dan sekedarnya saja, sekarang sudah mulai 
terbarukan dengan intensitas kebiasaan dan kesadaran yang lebih prima. Kebiasaan bersedekah dan berinfaq ini umumnya dilakukan oleh ummat muslim pada bulan-bulan ibadah wajib seperti bulan romadhon, bulan syawal atau bulan-bulan tertentu lainnya yang itupun terkantung dan terbatas pada uang recehan atau uang kecil yang tidak benar-benar disisihkan dan diniatkan kecuali untuk sedekah biasa saja demi menghargai bulan suci dan bulan ibadah demi untuk meningkatkan amal jariah semata.

Meskipun hikmah sedekah atau infaq sangat dirasakan bagi mereka yang menjalankannya, namun karena ini ibadah yang sunnah sehingga praktek ibadah yang manfaatnya luar biasa ini belum benar-benar disadari sebagai bentuk praktek muamalah yang intinya saling tolong menolong dan mensejahterakan semua ummat. Bentuk kesejahteraan itu bukan saja dirasakan oleh yang bersedekah ataupun berinfaq, tetapi juga dirasakan oleh kaum yang menerima sedekah dan infaq tersebut. Dan efek yang luar biasa dengan kebiasaan bersedekah dan berinfaq ini justru mampu membawakebahagiaan lahir batin bagi semua ummat. Sebagaimana perintah Allah dalam Q.S. Al-Baqarah 195.Artinya: Dan belanjakanlah (barta bendamu) di jalan Allah, dan janganlah kamu menjatubkan dirimu sendiri ke dalam kebinasaan, dan berbuat baiklah, karena sesunggubnya Allah menyukai orang-orang yang berbuat baik. (QS. Al-Baqarah: 195)

Seperti juga kata Rasulullah dalam hadist shahihnya yaitu:

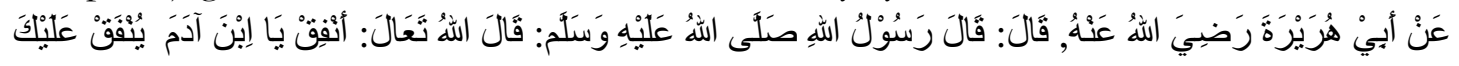

Artinya: Dari Abu Hurairah ra berkata, Rasulullah saw bersabda: "Allah swt berfirman, berinfaklah wahai anak. Adam, pasti (Aku) menggantinya."(HR. Muttafaq Alaih)

Berlandaskan pada perintah dan hadis Rasulullah tersebutlah maka beberapa lembaga, institusi dan badan-badan sosial keagamaan berlomba membangun kesadaran ummat dengan memfasilitasi penampungan dan penyaluran dana tersebut kepada ummat yang benar-benar membutuhkan. Bahkan sekarang ini sudah mulai dipikirkan bagaimana bentuk pendayagunaan dana-dana tersebut demi kesejahteraan ummat seluruhnya. Paling tidak dapat menyentuh bagi ummat yang benar-benar membutuh. Sebagaimana diketahui di setiap provinsi dan kabupaten memiliki BAZNAS untuk mengelola dana zakat, infak dan sedekah. SeSedangkan untuk di setiap desa pengelolaan dana tersebut dikelola melalui LAZ (Lembaga Amil Zakat) ataupun BMT.

Dengan demikian, ada kebebasan bagi pemiliknya untuk menyalurkan kemana ia berkehendak untuk menyalurkan harta kekayaannya itu. Namun demikian, ketentuan dan prioritas pada infaq itu tidaklah harus dipahami, bahwa infaq itu tidak boleh diberikan kepada orang yang jauh/bukan kerabatnya dengan orang yang menginfaqkan. pendistribusian infaq tersebut maka sekarang ini pengelolaannya sedekah dan infaq tersebut sudah mulai dikelola oleh beberapa lembaga yang kompeten seperti Baznas, Laznas dan beberapa BMT di beberapa daerah, kota dan desa-desa di seluruh Indonesia. Pengelolaan ini amatlah penting mengingat dana infaq dan sedekah merupakan suatu bentuk ibadah yang bias menghasilkan pendapatan perekonomian yang cukup besar di kalangan kaum muslim. Dana infaq yang dikelola oleh BMT tersebut tidak hanya disalurkan dalam bentuk 
uang secara tunai kepada penerima yang berhak, melainkan dapat pula terwujud dalam bentuk pembelian bahan-bahan usaha perekonomian demi peningkatkan kesejahteraan tiap rumah tangga ummat seluruhnya. Seperti, pengadaan pembelian alat-alat dan mesin pertanian yang berguna bagi petani.

Berangkat dari perintah berdakwah dan penggalangan kesadaran akan pentingnya kesadaran bersedekah dan berinfaq bagi ummat inilah akhirnya menginspirasi sebuah lembaga perekonomian kemasyarakat di Desa Saleh Jaya Banyu Asin yang tergabung dalam kelompok tani yang berwujud BMT (Baitul Mal wa Tamwi) dengan nama BMT Saleh Jaya. Peran dan tugas BMT ini selain menampung dana sedekah dan infaq anggota, juga menerima dana sedekah dan infaq dari ummat sekitar yang ingin disalurkan dananya kepada yang berhak mendapatkannya.

Hal yang paling menarik dari program penyaluran dan pendistribusian dana sedekah dan infaq ini pihak BMT Desa Saleh Jaya mengelolanya dalam bentuk pembelian bibit dan alat-alat atau mesin-mesin pertanian yang dkenal dengan nama program ALSINTAN. Program ALSINTAN ini dilaksanakan dari petani ke petani. Artinya pemanfaat dana infaq dan sedekah dari petani kaya di Desa Saleh Jaya oleh pihka BMT di salurhkan ke petani miskin di Desa Saleh Jaya dengan cara dibelikan bibit dan mesin pertanian. Penggunaan alat dan mesin pertanian selain dari bagian komponen penunjang dalam proses produksi juga merupakan wujud program pemerintah dalam merespon situasi pemanasan global yang mengakibatkan iklim pertanian tidak menentu sehingga perberasan nasional tidak stabil. Program tersebut dinamakan Peningkatan Produksi Beras Nasional (P2BN).

Dalam pembangunan agroindustri menurut Rahmat dan Hediarto alat dan mesin pertanian disebut dengan Alsintan.Dalam rangka pengembangan usaha tani padi, alsintan mempunyai peranan penting dalam kaitannya dengan sumber-sumber pertumbuhan dengan peningkatan dan diversifikasi produksi, peningkatan efisiensi dan pendapatan usahatani serta pengembangan agribisnis. Penggunaan alsintan dapat meningkatkan intensitas tanam dan ekstensifitas serta keserempakan pengelolaan usahatani yang sekaligus dapat mengurangi serangan hama dan penyakit.

Selain itu, menurut Daulay berbagai manfaat lain yang dapat diperoleh dengan penggunaan alsintan adalah penurunan upah tenaga kerja yang merupakan komponen biaya produksi yang cukup besar, peningkatan produktifitas lahan dengan tercapainya tanah yang lebih sempurna, percepatan waktu dalam penanaman, pemeliharaan dan panen, serta mengurangi kerugian akibat kehilangan hasil disaat panen.

Mengingat Sumatera Selatan memiliki luas wilayah 87.421,24 km2 dengan luas lahan pertanian 1.354 .847 ha yang terbagi dalam 4 wilayah kota dan 13 kabupaten. Sektor pertanian merupakan salah satu sektor yang memiliki peranan penting dalam perekonomian di Sumatera Selatan yang mana diantaranya sebagai lapangan pekerjaan dan sumber pendapatan bagi masyarakat. Hal ini sebagaimana data dari Badan Pusat Statistik (BPS) pada tahun 2016 bahwa salah satu lapangan usaha yang berperan dalam PDRB Sumatera Selatan yaitu lapangan usaha dari sektor pertanian sebesar 16,06 persen. 
Peranan penting sektor pertanian dalam pembentukan PDRB Sumatera Selatan tentunya berasal dari sumbangsi be berbagai wilayah kota/kabupaten yang ada, salah satunya kabupaten Banyuasin, tepatnya di kecamatan Air Salek di desa Saleh Jaya. Penduduk desa Saleh Jaya mayoritasbermata pencaharian sebagai petani padi. Produksi padi merupakan sektor ekonomi utama dalam pembentukan produk domestik regional bruto (PDRB) atau pendapatan masyarakatnya.

Adapun alur pendayagunaan dana infaq dan sedekah secara keseluruhan dapat di lihat pada gambar di bawah ini :

\section{Gambar 1}

Pendayagunaan Dana Infaq dan Sedekah

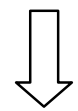

Dikembalikan dalam bentuk SHU

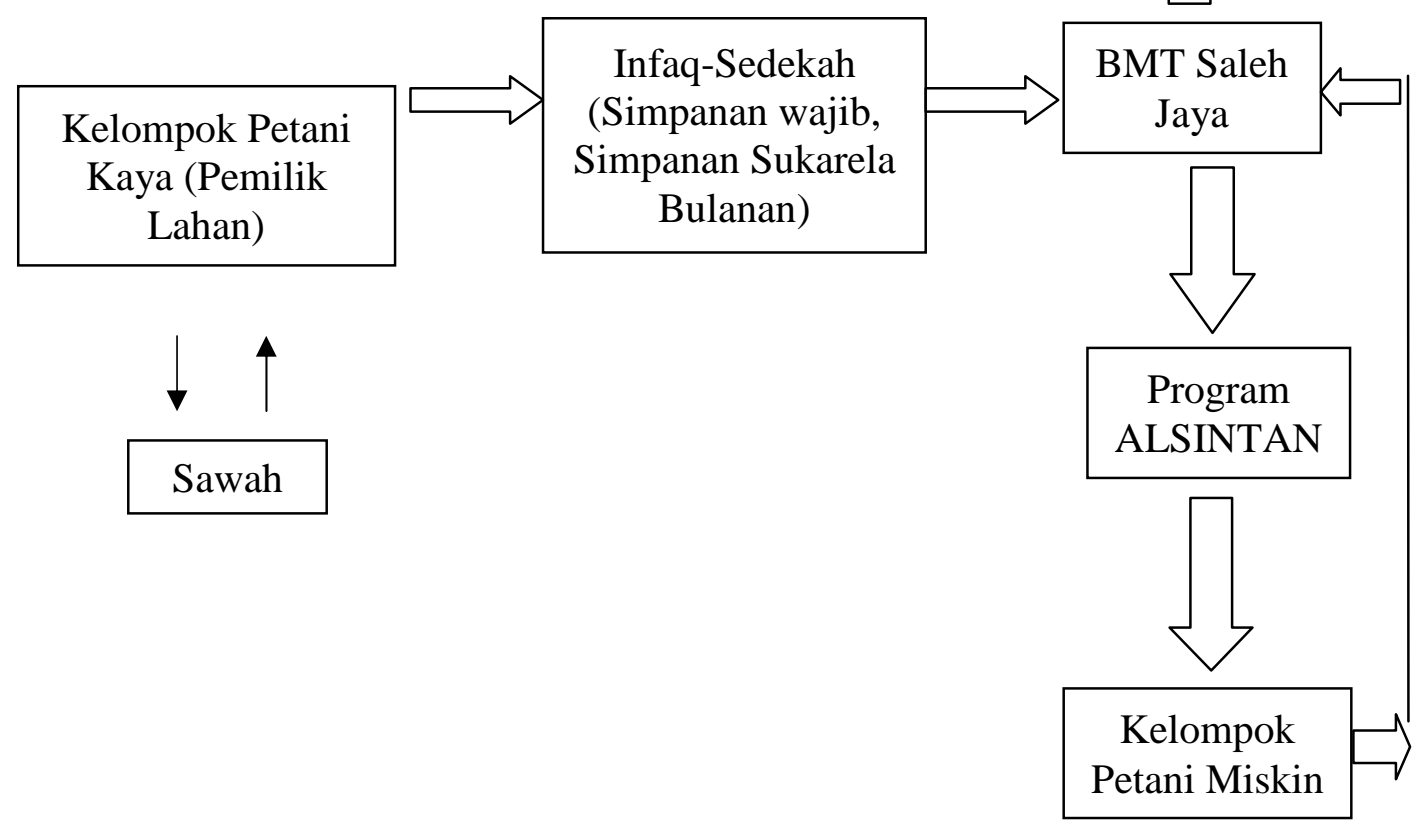

Jadi, maksud dari alur di atas adalah : dimana kelompok petani kaya (pemilik lahan) yang menjadi anggota BMT Saleh Jaya diwajibkan menyetorkan dana hasil pertaniannya dalam bentuk simpanan wajib dan simpanan sukarela disebut sebagai infaq dan sedekah yang telah ditentukan uangnya setiap panen. Dimana hasil panen itu yang lebih dulu mereka dapatkan dari program ALSINTAN yang mereka beli sebelumnya diserahkan secara cicilan bulanan (tetap) ke BMT Saleh Jaya.

Kemudian, pihak BMT Saleh jaya selaku pengelola menyimpankan uang hasil panen petani kaya dalam bentuk simpanan wajib dan simpanan sukarela. Uang simpanan wajib dan simpanan sukarela tersebut atas yang digolongkan infaq dan sedekah bagi BMT Saleh Jaya kemudian dikelola oleh BMT dengan dialokasikan dan didayagunakan melalui program ALSINTAN yang dari program tersebut menghasilkan keuntungan yang dapat diterima 
petani kaya dari petani miskin dan petani miskin pun dapat mengajak kelompok petani lainnya yang nantinya dapat memberikan keuntungan dan meningkatkan pendapatan semua petani.

Berangkat dari kenyataan tersebut maka peneliti tertarik untuk mengangakatnya menjadi studi kasus yang dilakukan secara ilmiah dalam bentuk penelitian kompetitif.

1. Rumusan Masalah:

a. Bagaimana bentuk pengumpulan dan pembinaan dana infaq dan sedekah dari petani ke petani yang dilakukan oleh BMT Saleh Jaya?

b. Bagaimana bentuk pengelolaan dana infaq dan sedekah melalui program Alsintan yang dilakukan oleh BMT Saleh Jaya?

c. Seberapa besar bentuk kebermanfaatan program Alsintan dalam mensejahterakan ummat di luar desa Saleh Jaya?

2. Tujuan Penelitian

a. Untuk mengetahui bentuk pengumpulan dan pembinaan dana infaq dan sedekah dari petani ke petani yang dilakukan oleh BMT Saleh Jaya?

b. Untuk mengetahui bentuk pengelolaan dana infaq dan sedekah melalui program Alsintan yang dilakukan oleh BMT Saleh Jaya?

c. Untuk menganalisis seberapa besar bentuk kebermanfaatan program Alsintan dalam mensejahterakan ummat di luar desa Saleh Jaya?

3. Kajian Pustaka

Sebagai bahan perbandingan antara penelitian yang dilakukan penulis dengan penelitian sebelumnya, maka ditemukanlah beberapa referensi yang dapat dijadikan pembanding tersebut dari penelitian sebelumnya, diantaranya:

Sumadi (2017) dengan penelitian Optimalisasi Dana Zakat, Infaq, Sadaqah dalam Pemertaan Ekonomi di Kabupaten Sukoharjo (Studi Kasus di Badan Amil Zakat Daerah Kab. Sukoharjo). Penelitian yang dilakukannya memiliki kesimpulan bahwa zakat, infaq, dan sadaqah merupakan dana potensial yang dapat dimanfaatkan untuk mensejahterakan bagi seluruh masyarakat terutama dana zakat. Namun, dana potensial tersebut agar memang dapat bermanfaat dalam mengatasi berbagai permasalahan ekonomi seperti kemiskinan dan kesenjangan sosial, maka dana tersebut harus dikelola oleh tenaga profesional dan bertanggung jawab yang dalam hal ini BAZNAS dan BAZDA di daerah Sukoharjo sehingga nantinya pengelolaan dana ZIS lebih terarah dan terukur.

Muhajirin (2017) dengan Potensi dan Kontribusi Zakat, Infaq, dan Shadaqah dalam Peningkatan Ekonomi dan Pendidikan (Studi Kasus di Wilayah Kota Bogor). Beliau menyimpulkan dari hasil penelitiannya bahwa konsep atau aturan distribusi ZIS kota Bgor adalah mengalokasikan dana ZIS kepada pihak mustahiq namun lebih mengarah pada zakat produktif seperti dialokasikan untuk bantuan pendidikan siswa atau mahasiswa berprestasi namun tidak mampu secara ekonomi, bantuan kepada guru ngaji, bantuan modal bagi pedagang baik dengan sistim mudharabah maupun atas nama mustahiq, bantuan kesehatan serta pengembangan dakwah di kota Bogor. Kontribusinya bagi perbaikan ekonomi dan pendidikan bagi kaum muslimin khususnya warga kota Bogor adalah terealisasinya program 
zakat produktif baik dalam bidang keagamaan, pendidikan, sosial, maupun ekonomi, hal ini bisa dilihat dari berjalannya semua program yang sudah direncanakan pada tahun sebelumnya yang sudah banyak membantu program-program pemerintah daerah maupun pemerintah pusat.

Muhammad Amin Suma (2013) dengan penelitian Zakat, Infak, dan Sedekab: Modal dan Model Ideal Pembangunan Ekonomi dan Kenangan Modern. Hasil penelitian beliau menyimpulkan bahwa zakat, infak, dan sedekah (ZIS) bisa dijadikan modal dan sekaligus model pembangunan sistem ekonomi dan keuangan sepanjang zaman. Hal ini dikarenakan selain dana ZIS sudah pernah teruji ketahanan dan keberlangsungannya dalam sepanjang perjalanan sejarah peradaban Islam sebagai dana cadangan yang mampu untuk selalu siap dicairkan dalam berbagai situasi dan kondisi, terutama untuk mengatasi berbagai permasalahan ekonomi dan keuangan. Selain itu, hal ini pun didukung dari potensi dana ZIS yang tak pernah berkurang di semua negara yang penduduknya mayoritas Islam termasuk Indonesia.

\section{LITERATUR REVIEW}

\section{Teori Pendapatan}

Pendapatan adalah jumlah total penerimaan uang ataupun penghasilan yang diterima oleh seseorang, suatu rumah tangga, atau karyawan atas prestasi kerjanya selama satu periode tertentu baik harian, mingguan, bulanan, atau tahunan.Menurut Winardi (Subandriyo, 2016:54), pendapatan adalah hasil berupa uang atau hasil material yang dicapaidari penggunaan barang atau jasa-jasa manusia secara bebas.Sedangkanmenurut Akuntansi Keuangan (Fuad, dkk, 2000:168), pendapatan didefinisikan sebagai peningkatan jumlah aktiva atau penurunan kewajiban, sebagai akibat dari penjualan barang dan jasa kepada pihak lain dalam periode akuntansi tertentu.Berdasarkan dari berbagai teori di atas maka pendapatan dapat diartikan sebagai semua penghasilan atau sesuatu yang menyebabkan bertambahnya kemampuan seseorang dalam konsumsi maupun tabungan dan dapat orang tersebut gunakan untuk memenuhi kebutuhan hidupnya dalam mencapai kepuasan.

\section{Teori Infaq-Sedekah}

Infaq secara bahasa berasal dari kata infaqa yang berarti mengeluarkan sesuatu untuk kepentingan sesuatu. Sementara menurut istilah syariat, infaq berarti mengeluarkan sebagian dari harta atau pendapatan atau penghasilan untuk suatu kepentingan yang yang diperintahakan agama Islam. Jika zakat ada nisbahnya, maka infaq dan shadaqah terbebas dari nisab.

Selain itu kata infaq berarti mendermakan harta yang diberikan Allah SWT, menafkahkan sesuatu pada orang lain semata-mata mengharap ridha Allah SWT. Dengan demikian, infaq merupakan bentuk pentasharufan harta sesuai dengan tuntunan syariah.Infaq juga dapat diartikan sebagai sesuatau yang dikeluarkan sebagai tambahan dari zakat, yang bersifat sukarela yang diambil dari harta atau kekayaan seseorang kemaslahatan 
umum atau membantu yang lemah dan dipergunakan sebagaimana mestinya utnuk kepentingan umat.

Adapun perbedaan infaq dan zakat dapat dilihat dari waktu pengeluarannya, dalam zakat ada nisbahnya sedangkan infaq tidak ada, baik dia berpenghasilan tinggi maupun rendah. Zakat diperuntukkan untuk delapan ashnaf, sedangkan infaq dapat diberikan kepada siapapun juga, misalnya untuk keluarga, anak yatim, dan lain-lain. Infaq tidak ditentukan jenisnya, jumlah dan kadarnya, serta waktu penyerahannya.Sedangkan, shadaqah berasal dari bahasa arab Shadaqa. Didalam Al-Munjid kata shadaqah diartikan yang niatnya mendapatkan pahala dari Allah, bukan sebagai penghormatan. Secara umum dapat diartikan bahwa, sedekah adalah pemberian dari seorang muslim secara sukarela tanpa dibatasi waktu dan jumlah (haul dan nisbah) sebagai kebaikan dengan menharap ridho Allah.

\section{METODE PENELITIAN}

1. Pendekatan dan Jenis Penelitian

Pada penelitian ini peneliti menggunakan penelitian mixed methods, yang mana penelitian ini dapat diartikan sebagai metode penelitian yang mengkombinasikan antara dua metode penelitian sekaligus, yaitu kualitatif dan kuantitatif dalam suatu kegiatan penelitian yang nantinya akan diperoleh data yang lebih komprehensif, valid, reliabel, dan objektif.

2. Populasi dan Sampel

Populasi dalam penelitian ini yaitu petani di desa Saleh Jaya, Banyuasin, yang berjumlah 793 KK.Alasan dipilihnya petani di desa Saleh Jaya karena belum pernah dilakukan penelitian sebelumnya, jumlah populasinya cukup banyak, dan fenomena yang terjadi di lapangan mengenai pengelolaan dana infaq dan sedekah yang menarik melalui program ALSINTAN.

Teknik sampling dalam penelitian ini yaitu simple random sampling, yang mana simplerandom sampling merupakan teknik pengambilan sampel yang memberikan kesempatan yang sama kepada populasi untuk dijadikan sampel.Adapun dipilihnya teknik simple random sampling karena anggota populasi relatif homogen. Jumlah sampel dalam penelitian ini berjumlah 40 petani.

3. Jenis dan Sumber Data

a. Data Primer

Data primer didapatkan atau dikumpulkan langsung dari lapangan oleh orang yang melakukan penelitian atau yang memerlukannya.Dalam hal ini, data primer diperoleh dari hasil jawaban responden yaitu petani di desa Saleh Jaya, Banyuasin atas pengisian kuesioner/angket, wawancara, dan observasi yang telah dilakukan.

b. Data Sekunder

Data sekunder diperoleh dalam bentuk yang sudah jadi, sudah dikumpulkan dan diolah oleh pihak lain, biasanya dalam bentuk publikasi. Data sekunder dipergunakan untuk menunjang data primer yang berasal dari literatur, jurnal, dan buku-buku penelitian. Data sekunder merupakan struktur data historis mengenai variabel-variabel 
yang telah dikumpulkan dan dihimpun sebelumnya oleh pihak lain. Sumber data sekunder bisa diperoleh dari dalam suatu instansi, berbagai internet websites, perpustakaan umum maupun lembaga pendidikan, membeli dari instansi-instansi yang memang mengkhususkan diri untuk menyajikan data sekunder.

4. Teknik Pengumpulan Data

Penelitian ini menggunakan seluruh teknik pengumpulan data diantaranya:

\section{a. Observasi}

Teknik pengumpulan data menggunakan observasi dilakukan untuk mengukur sikap dari responden yang nantinya didukung dengan wawancara dan angket. Selain itu, teknik ini pun dapat digunakan untuk merekam berbagai fenomena yang terjadi (situasi, kondisi).

b. Angket/Kuesioner

Pada penelitian ini, penulis menggunakan metode pengumpulan data dengan angket/kuesioner. Dipilihnya kuesioner/angket sebagai metode pengumpulan datadikarenakan kuesioner/angket merupakan teknik pengumpulan data yang efisien dan cocok untuk jumlah responden yang cukup besar. Kuesioner/angket terdiri dari beberapa jenis yaitu angket terbuka, angket tertutup, dan angket campuran. Dari ketiga jenis tersebut, penulis menggunakan jenis angket/kuesioner tertutup. Dalam kuesioner ini tugas responden adalah memilih satu atau lebih kemungkinan-kemungkinan jawaban yang telah disediakan.

Desain pengukuran dalam penelitian ini menggunakan skala likert. Skala likert digunakan untuk mengukur sikap, pendapat dan persepsi seseorang atau sekelompok orang tentang fenomena sosial.Dengan menggunakan skala likert, maka variabelvariabel penelitian akan dijabarkan dan diukur dengan indikator dari setiap variabel. Setiap indikator dari masing-masing variabel menjadi titik tolak penyusunan item-item instrumen pertanyaan. Jawaban dari setiap item instrumen yang menggunakan skala likert mempunyai gradiasi dari sangat positif sampai sangat negatif.

c. Wawancara

Wawancara merupakan teknik pengumpulan data yang dilakukan melalui tatap muka dan tanya jawab langsung antara peneliti ddengan responden. Teknik ini bertujuan untuk mengetahui hal-hal yang lebih mendalam dari responden .

5. Teknik Analisis Data

Dalam penelitian ini analisis data yang digunakan yaitu analisis kuantitatif dan kualitatif bertahap, yang mana analisis data ini dimulai dari analisis data kuantitatif diikuti pengumpulan analisis data kualitatif.

\section{HASIL PENELITIAN}

\section{Pengumpulan dan Pembinaan Dana Infaq-Sedekah}

Dana infaq dan sedekah dikumpulkan oleh sebuah lembaga agama kemasyarakatan seperti di Badan Kepengurusan Masjid (BKM), Lembaga Amil Zakat (LAZ), Badan Amil Zakat (BAZ), Baitul Mal wa Tamwil (BMT), ataupun lembaga lainnya. Dana tersebut 
dikumpulkan dan nantinya akan dikelola dengan baik oleh lembaga-lembaga yang bersangkutan. Seperti halnya zakat, dana infaq dan sedekah pun tentulah sangat potensial untuk dikelola.Kelompok tani di bagi menjadi 2, yaitu Kelompok Tani Kaya yang dimaksud dengan kelompok tani kaya pada pembahasan ini yaitu sebuah kelompok tani yang di dalamnya mencakup para petani yang memiliki lahan berkisar antara 2-5 hektar sawah dengan rata-rata pendapatan minimal Rp.15.000.000/tahun.Kelompok tani kaya dalam hal ini dapat dikatakan sebagai kumpulan para petani yang telah maju, baik dari penggunaan peralatan dan perlengkapan pertanian maupun dari pendapatan pertanian. Para petani dalam kelompok ini telah menggunakan alat dan mesin pertanian yang dapat membantu mereka dalam meningkatkan hasil produksi sehingga berdampak positif pula pada pendapatan mereka.

Kelompok tani miskin merupakan kelompok tani yang memiliki kendala dalam pengembangan usaha pertaniannya, baik dari segi peralatan maupun perlengkapannya. Lahan yang mereka miliki pun hanya berkisar $100 \mathrm{~m}^{2}$ hingga $1.000 \mathrm{~m}^{2}$ (1 ha).Dalam hal ini, bantuan yang diberikan kepada para petani miskin yaitu berupa bibit, racun hama, alat dan mesin pertanian yang dapat mereka gunakan secara gratis, serta penyuluhan-penyuluhan dari para petugas pertanian. Mereka tentunya perlu untuk dibimbing dan diarahkan. Walaupun lahan yang mereka miliki tak seberapa luas, namun mereka dapat menuai hasil yang maksimal, hingga pada akhirnya akan meningkatkan pendapatan mereka dan mensejahterakan hidup mereka.

\section{Pengelolaan Alsintan dengan Dana Infaq-Sedekah}

Setiap bulannya para petani yang dalam hal ini yaitu petani kaya yang artinya mereka memiliki keunggulan dalam kegiatan pertaniannya selalu melakukan infaq dan sedekah. Sebenarnya bukan karena kewajiban mereka sebagai anggota BMT Saleh Jaya, melainkan dikarenakan adanya kesadaran dari dalam diri mereka mengenai pentingnya melaksanakan infaq dan sedekah. Dasar prosedur pengelolaan dana infaq adalah memberi rezki, berupa karunia Alah atau menafkahkan hartanya pada orang lain dengan ikhlas karena Allah. Infaq menyerahkan harta atau nilainya dari perorangan atau badan hukum untuk diberikan kepada seseorang karena kebutuhan, mengurangi penderitaan masyarakat, memelihara ketentraman, menghindari hal-hal yang tidak diinginkan.

\section{Pemanfaatan Program Alsintan dalam Mensejahterakan Ummat}

Upaya dalam rangka peningkatan daya saing dan nilai tambah produk pertanian adalah dengan meningkatkan efisiensi, produktivitas, dan mutu produk pertanian. Peningkatan efisiensi, produktivitas dan mutu produk pertanian membutuhkan sentuhan mekanisasi pertanian, di samping sangat ditentukan oleh modal dan kualitas sumber daya manusia. Dalam hal ini alsintan dirasa pas dan cocok untuk membantu meningkatkan hasil produksi padi petani dan membantu mensejahterakan masyarakat. Alsintan mempunyai peranan penting dalam kaitannya dengan sumber-sumber pertumbuhan dengan peningkatan dan diversifikasi produksi, peningkatan efisiensi dan pendapatan usahatani serta pengembangan agribisnis. Penggunaan alsintan dapat meningkatkan intensitas tanam dan ekstensifitas serta keserempakan pengelolaan usahatani yang sekaligus dapat mengurangi serangan hama dan penyakit. 


\section{PEMBAHASAN}

\section{Pengumpulan dan Pembinaan Dana Infaq-Sedekah}

Dana infaq dan sedekah tersebut biasanya dikumpulkan oleh sebuah lembaga agama kemasyarakatan seperti di Badan Kepengurusan Masjid (BKM), Lembaga Amil Zakat (LAZ), Badan Amil Zakat (BAZ), Baitul Mal wa Tamwil (BMT), ataupun lembaga lainnya. Dana tersebut dikumpulkan dan nantinya akan dikelola dengan baik oleh lembaga-lembaga yang bersangkutan. Seperti halnya zakat, dana infaq dan sedekah pun tentulah sangat potensial untuk dikelola. Saat ini pun infaq dan sedekah terus dibudayakan agar dapat membantu perekonomian umat. Dalam hal ini sesuai judul yang diambil oleh peneliti bahwa dana infaq dan sedekah dapat dioptimalisasikan dalam rangka meningkatkan pendapatan masyarakat sehingga nantinya berdampak baik bagi kesejahteraan ummat. Peneliti berfokus pada sebuah desa yang ada di Banyuasin Sumatera Selatan yang dalam hal ini telah membudayakan kegiatan berinfaq dan sedekah melalui sebuah BMT dan mayoritas penduduknya merupakan bermata pencaharian sebagai petani, yaitu desa Saleh Jaya Banyuasin. Tujuan mereka membudayakan kegiatan berinfaq dan sedekah tersebut sangatlah simpel namun memiliki makna yang sangat luar biasa yaitu ibadah dan sejahtera bersama.

\section{a. Kelompok Tani}

1) Kelompok Tani Kaya

Yang dimaksud dengan kelompok tani kaya pada pembahasan ini yaitu sebuah kelompok tani yang di dalamnya mencakup para petani yang memiliki lahan berkisar antara 2-5 hektar sawah dengan rata-rata pendapatan minimal Rp.15.000.000/tahun.

Kelompok tani kaya dalam hal ini dapat dikatakan sebagai kumpulan para petani yang telah maju, baik dari penggunaan peralatan dan perlengkapan pertanian maupun dari pendapatan pertanian. Para petani dalam kelompok ini telah menggunakan alatdan mesin pertanian yang dapat membantu mereka dalam meningkatkan hasil produksi sehingga berdampak positif pula pada pendapatan mereka.

2) Kelompok Tani Miskin

Kelompok tani miskin merupakan kelompok tani yang memiliki kendala dalam pengembangan usaha pertaniannya, baik dari segi peralatan maupun perlengkapannya. Lahan yang mereka miliki pun hanya berkisar $100 \mathrm{~m}^{2}$ hingga $1.000 \mathrm{~m}^{2}(1 \mathrm{ha})$.

Dalam pelaksanaan usaha pertaniannya, para petani dalam kelompok tani ini mendapatkan bantuan dari BMT Saleh Jaya, yang mana BMT ini merupakan hasil dari pembentukan kelompok tani kaya yang ini membantu para petani lainnya sehingga tercapailah visi dan misinya yaitu ibadah dan sejahtera bersama. Bantuan yang biasa mereka dapatkan tidak berupa uang, melainkan bantuan dalam hal peralatan dan perlengkapan mereka untuk dapat melaksanakan pertanian dengan baik dan lancar.

\section{Pengelolaan Alsintan dengan Dana Infaq-Sedekah}

Setiap bulannya para petani yang dalam hal ini yaitu petani kaya yang artinya mereka memiliki keunggulan dalam kegiatan pertaniannya selalu melakukan infaq dan sedekah. Sebenarnya bukan karena kewajiban mereka sebagai anggota BMT Saleh Jaya, melainkan 
dikarenakan adanya kesadaran dari dalam diri mereka mengenai pentingnya melaksanakan infaq dan sedekah.

Dana ifaq dan sedekah para petani kumpulkan di BMT Saleh Jaya untuk dikeloa. Dasar prosedur pengelolaan dana infaq adalah memberi rezki, berupa karunia Alah atau menafkahkan hartanya pada orang lain dengan ikhlas karena Allah. Infaq menyerahkan harta atau nilainya dari perorangan atau badan hukum untuk diberikan kepada seseorang karena kebutuhan, mengurangi penderitaan masyarakat, memelihara ketentraman, menghindari hal-hal yang tidak diinginkan. Dasar prosedur pengelolaan dana infaq pertama dari al-Qur'an kedua dari Undang-Undang LAZ.

Bagi kebanyakan lembaga yang mengelola dana infaq, memang penyaluran dana tunai selama ini ditujukan kepada Muallaf, Ghorimin, Fakir, Miskin dan Amilin. Tetapi porsi dana tunai lebih sedikit dibandingkan dengan dana untuk membiayai program-program pemberdayaan yang banyak berkaitan dengan program sosial, kemanusiaan, pemodalan usaha produktif, penyuluhan sosial ekonomi, pembangunan sarana ibadah dan perawatan kesehatan dan sebagainya.

\section{Pemanfaatan Program Alsintan dalam Mensejahterakan Ummat}

Upaya peningkatan produksi padi dapat terwujud dengan penyempurnaan manajemen teknis yang diantaranya adalah percepatan pengolahan tanah dan penanaman secara serentak. Upaya dalam rangka peningkatan daya saing dan nilai tambah produk pertanian adalah dengan meningkatkan efisiensi, produktivitas, dan mutu produk pertanian. Peningkatan efisiensi, produktivitas dan mutu produk pertanian membutuhkan sentuhan mekanisasi pertanian, di samping sangat ditentukan oleh modal dan kualitas sumber daya manusia.

Dalam hal ini alsintan dirasa pas dan cocok untuk membantu meningkatkan hasil produksi padi petani dan membantu mensejahterakan masyarakat. Alsintan mempunyai peranan penting dalam kaitannya dengan sumber-sumber pertumbuhan dengan peningkatan dan diversifikasi produksi, peningkatan efisiensi dan pendapatan usahatani serta pengembangan agribisnis. Penggunaan alsintan dapat meningkatkan intensitas tanam dan ekstensifitas serta keserempakan pengelolaan usahatani yang sekaligus dapat mengurangi serangan hama dan penyakit.

a. Konstanta

Pada penelitian ini dari hasil analisis regresi linier berganda diperoleh nilai konstanta sebesar 2,094 yang diartikan jika variabel bebas (independen) yaitu biaya produksi, jumlah produksi, dan harga jual padiberada dalam model yang sama $=0$ (nol), maka secara ratarata variabel di luar model memberikan nilai pada pendapatan petani sebesar 2,094.

b. Koefisien $\mathrm{X}_{1}$

Koefisien $\mathrm{X}_{1}$ yaitu koefisien regresi biaya produksi memiliki nilai positif sebesar 0,257, artinya apabila biaya produksi mengalami perubahan sebesar 1 rupiah maka akan meningkatkan pendapatan petani sebesar 0,257. 


\section{c. Koefisien $\mathrm{X}_{2}$}

Koefisien $\mathrm{X}_{2}$ yaitu koefisien regresi jumlah produksi memiliki nilai positif sebesar 0,303, artinya apabila jumlah produksi mengalami peningkatan sebesar $1 \mathrm{~kg}$ maka akan meningkatkan pendapatan petani sebesar 0,303.

d. Koefisien $\mathrm{X}_{3}$

Koefisien $\mathrm{X}_{3}$ yaitu koefisien regresi harga jual padi memiliki nilai positif sebesar 0,330, artinya apabila harga jual padi mengalami peningkatan sebesar 1 rupiah maka akan meningkatkan pendapatan petani sebesar 0,330.

Dari berbagai uraian di atas, maka dapat disimpulkan bahwa pengoptimalan dana infaq dan sedekah yang dilakukan oleh pihak BMT Saleh Jaya dengan program alsintan atau program peminjaman alat dan mesin pertanian sangat mmbantu petani desa Saleh Jaya dalam meningkattkan pendapatan petani sehingga berdampak baik pula terhadap kesejahteraan ummat. Tujuan adanya program tersebut yang dilaksanakan oleh BMT Saleh Jaya pun terwujud dengan baik yaitu ibadah dan sejahtera bersama, yang dalam hal ini ibadah yaitu melaksanakan ibadah infaq dan sedekah, membantu sesama, dan sejahtera bersama karena petani kaya dan petani yang diberikan bantuan (petani miskin) sama-sama mendapat keuntungan sehingga petani miskin dapat membantu petani lainnya agar menmendapatkan keuntungan seperti yang mereka dapatkan yaitu peningkatan jumlah pendapatan dengan program alsintan sehingga kesejahteraan pun meningkat.

\section{KESIMPULAN}

1. Pengumpulan dan Pembinaan Dana Infaq-Sedekah

Dana infaq dan sedekah dikumpulkan oleh sebuah lembaga agama kemasyarakatan seperti di Badan Kepengurusan Masjid (BKM), Lembaga Amil Zakat (LAZ), Badan Amil Zakat (BAZ), Baitul Mal wa Tamwil (BMT), ataupun lembaga lainnya. Dana tersebut dikumpulkan dan nantinya akan dikelola dengan baik oleh lembaga-lembaga yang bersangkutan. Seperti halnya zakat, dana infaq dan sedekah pun tentulah sangat potensial untuk dikelola. Kelompok tani di bagi menjadi 2, yaitu Kelompok Tani Kaya yang dimaksud dengan kelompok tani kaya pada pembahasan ini yaitu sebuah kelompok tani yang di dalamnya mencakup para petani yang memiliki lahan berkisar antara 2-5 hektar sawah dengan rata-rata pendapatan minimal Rp.15.000.000/tahun. Kelompok tani kaya dalam hal ini dapat dikatakan sebagai kumpulan para petani yang telah maju, baik dari penggunaan peralatan dan perlengkapan pertanian maupun dari pendapatan pertanian. Para petani dalam kelompok ini telah menggunakan alat dan mesin pertanian yang dapat membantu mereka dalam meningkatkan hasil produksi sehingga berdampak positif pula pada pendapatan mereka.

Kelompok tani miskin merupakan kelompok tani yang memiliki kendala dalam pengembangan usaha pertaniannya, baik dari segi peralatan maupun perlengkapannya. Lahan yang mereka miliki pun hanya berkisar $100 \mathrm{~m} 2$ hingga $1.000 \mathrm{~m} 2$ (1 ha). Dalam hal ini, bantuan yang diberikan kepada para petani miskin yaitu berupa bibit, racun hama, alat dan mesin pertanian yang dapat mereka gunakan secara gratis, serta penyuluhan-penyuluhan 
dari para petugas pertanian. Mereka tentunya perlu untuk dibimbing dan diarahkan. Walaupun lahan yang mereka miliki tak seberapa luas, namun mereka dapat menuai hasil yang maksimal, hingga pada akhirnya akan meningkatkan pendapatan mereka dan mensejahterakan hidup mereka.

\section{Pengelolaan Alsintan dengan Dana Infaq-Sedekah}

Setiap bulannya para petani yang dalam hal ini yaitu petani kaya yang artinya mereka memiliki keunggulan dalam kegiatan pertaniannya selalu melakukan infaq dan sedekah. Sebenarnya bukan karena kewajiban mereka sebagai anggota BMT Saleh Jaya, melainkan dikarenakan adanya kesadaran dari dalam diri mereka mengenai pentingnya melaksanakan infaq dan sedekah. Dasar prosedur pengelolaan dana infaq adalah memberi rezki, berupa karunia Allah atau menafkahkan hartanya pada orang lain dengan ikhlas karena Allah. Infaq menyerahkan harta atau nilainya dari perorangan atau badan hukum untuk diberikan kepada seseorang karena kebutuhan, mengurangi penderitaan masyarakat, memelihara ketentraman, menghindari hal-hal yang tidak diinginkan.

3. Pemanfaatan Program Alsintan dalam Mensejahterakan Ummat

Upaya dalam rangka peningkatan daya saing dan nilai tambah produk pertanian adalah dengan meningkatkan efisiensi, produktivitas, dan mutu produk pertanian. Peningkatan efisiensi, produktivitas dan mutu produk pertanian membutuhkan sentuhan mekanisasi pertanian, di samping sangat ditentukan oleh modal dan kualitas sumber daya manusia. Dalam hal ini alsintan dirasa pas dan cocok untuk membantu meningkatkan hasil produksi padi petani dan membantu mensejahterakan masyarakat. Alsintan mempunyai peranan penting dalam kaitannya dengan sumber-sumber pertumbuhan dengan peningkatan dan didiversifikasi produksi, peningkatan efisiensi dan pendapatan usahatani serta pengembangan agribisnis. Penggunaan alsintan dapat meningkatkan intensitas tanam dan ekstensifitas serta keserempakan pengelolaan usahatani yang sekaligus dapat mengurangi serangan hama dan penyakit.

Dari berbagai uraian di atas, maka dapat disimpulkan bahwa pengoptimalan dana infaq dan sedekah yang dilakukan oleh pihak BMT Saleh Jaya dengan program alsintan atau program peminjaman alat dan mesin pertanian sangat mmbantu petani desa Saleh Jaya dalam meningkattkan pendapatan petani sehingga berdampak baik pula terhadap kesejahteraan ummat. Tujuan adanya program tersebut yang dilaksanakan oleh BMT Saleh Jaya pun terwujud dengan baik yaitu ibadah dan sejahtera bersama, yang dalam hal ini ibadah yaitu melaksanakan ibadah infaq dan sedekah, membantu sesama, dan sejahtera bersama karena petani kaya dan petani yang diberikan bantuan (petani miskin) sama-sama mendapat keuntungan sehingga petani miskin dapat membantu petani lainnya agar men mendapatkan keuntungan seperti yang mereka dapatkan yaitu peningkatan jumlah pendapatan dengan program alsintan sehingga kesejahteraan pun meningkat. 


\section{REFERENSI}

Budiman, Good Governance Pada Lembaga ZISW AF(Implementasi Pelibatan Pemangku Kepentingan dalam Pengelolaan ZISWAF), Semarang: Lembaga Penelitian IAIN Walisongo Semarang.

Ilmi Makhalul, Teori dan Praktik Lembaga Mikro Keuangan Syariah, Yogyakarta: UII Press, 2002.

Irfan el-Firdausy, Dasyatnya Sedekah Meraih Berkah Dari Sedekah, Yogyakarta: Cemerlang Publishing, 2009.

M. Fuad, dkk, Pengantar Bisnis,Jakarta: PT Gramedia Pustaka Utama, 2000

Sanusi, The Power of Sedekah, Yogyakarta: Pustaka Insan Madani, 2009

Sugiyono, Metode Penelitian Kualitatif, Kuantitatif dan R\&D, (Bandung: Alfabeta, 2011)

Suheiti, Kiki "Alat dan Mesin Pertanian Tepat Guna untuk Tanaman Padi dalam Mendukung Program Peningkatan Produksi Beras Nasional (P2BN)", JurnalBalai Pengkajian Teknologi Pertanian,http://jambi.litbang.pertanian.go.id, (diakses 20 September 2017, 05:30 WIB)

Suryani dan Hendryadi, Metode Riset Kuantitatif: Teori dan Aplikasi pada Penelitian Bidang Manajemen dan Ekonomi Islam, (Jakarta: Prenamedia Group, 2015), hal. 171

Togatorop, Boyma "Hubungan Teknologi Alsintan Terhadap Produktivitas Padi Sawah di Desa Sri Agung Kecamatan Batang Asam Kabupaten Tanjung Jabung Barat" Skripsi, (Jambi: Fakultas Pertanian Universitas Jambi, 2017), http://repository.unja.ac.id, (diakses, 19 September 2017, 05:30 WIB)

Umar,Sudirman, "Pengelolaan dan Pengembangan Alsintan untuk Mendukung Usahatani Padi di Lahan Pasang Surut", Jurnal Teknologi Pertanian, 8, No. 2:37-48. http://jtpunmul.files.wordpress.com, (diakses 12 Oktober 2018, 13:12 WIB) 